\title{
IN THE QUEST FOR COMPETITIVENESS: THE INFLUENCE BETWEEN FINANCIAL INDICATORS AND THE RATE OF COMMERCIAL PROFITABILITY (RCP) IN THE ROMANIAN RETAIL MARKET
}

\author{
Cârstea Gheorghe ${ }^{179}$ \\ Corboș Răzvan - Andrei ${ }^{180}$ \\ Măiță Nicolae Daniel ${ }^{181}$ \\ Bunea Ovidiu - Iulian ${ }^{182}$
}

https://doi.org/10.31410/itema.2018.446

\begin{abstract}
A major direction in Romanian retailing is the increasingly varied retail format available for the real consumer. Due to the new retail methods which developed in Romania in the last 3 years, the competition among the biggest retailers on the market is in a full growth, with still big development potential. The article focuses on how the financial indicators influence the rate of commercial profitability $(R C P)$ in the Romanian retail market. Also, this paper provides a lot of tangible effects of the actual indicators on the RCP. To achieve these results, we used a series of correlations and a multiple linear regression in order to predict the effects of the financial indicators on RCP. Therefore, we have formulated a series of characteristic features of the retail companies in Romania through the RCP indicator and we have found that we have an extensive interaction between the financial indicators and the RCP of the studied companies.
\end{abstract}

Keywords: competitiveness, financial indicators, rate of commercial profitability, retail market

\section{INTRODUCTION}

$\mathrm{T}$ The FMCG industry (Fast Moving Consumer Goods Industry) has developed a lot in the last period of time, especially in the last 5 years, worldwide. This industry has had a big impact on global economy, especially in less developed countries from Europe, South Africa and Asia. Here, the development potential has reached a high level due to a great desire for development in every economic sector. As a conclusion to this affirmation, today, in almost every state, all over the world, there is a lot of "new markets system" which allows you to serve yourself, go through the shelves and select what you want to purchase.

Lately, we can see a new trend regarding retail store locations. They are located in big or small cities, near customer's houses, with easy walking distance, easy to access for everyone, stretched all over the city place. Regarding this trend, we could discover a series of determined factors, which lead to this big increase in Romanian markets in this sector, especially when we identified that in last 8 years, it was an equal weight between modern and traditional trade in our country. (Deac et al., 2016). Due to increasing purchasing power, the changes in people's

\footnotetext{
${ }^{179}$ Bucharest University of Economic Studies, 6, Romana Square, District 1, Bucharest, Romania

${ }^{180}$ Bucharest University of Economic Studies, 6, Romana Square, District 1, Bucharest, Romania

${ }^{181}$ Bucharest University of Economic Studies, 6, Romana Square, District 1, Bucharest, Romania

182 Bucharest University of Economic Studies, 6, Romana Square, District 1, Bucharest, Romania
} 
consumption comportment and the development of modern trade, the Romanian retail market is on the rise and could be the best East-European retail market in the future. (Retail-FMCG.ro, 2017)

\section{PROBLEM DESCRIPTION}

Retail industry, in Romania economy, is being considered one of the most developed and largest sectors, registering the highest increase of the retail volume from the entire Europe in 2018, until now. After a careful analysis at the beginning of 2018, we've found out that the value of Romanian retail market is over $€ 20$ billion. The last official statements indicate that in 2017, FMCG sector contributed 6,9\% to the GDP of Romania, which represent an amount over $€ 17$ billion. The profits of international retailers in Romania is at the same time directly proportional with the volume of sales and also the price of the product itself, knowing that the most common practice in retail world is the lowest price technique. (Ryu, J., Pistikopoulos, E.N., 2007)

Being a profitable industry, with an efficient distribution network, with a big presence of a multinational corporations and a lot of good competitors, FMCG is and will be one of the main engines of the global economy.

The quantitative indicators such as fixed assets, current assets, number of employees, stocks, fiscal value, have a big influence to those qualitative indicators presented above and all of them have an important influence to our principal indicator, RCP (rate of commercial profitability). A laborious enquiry can explain that all the quantitative indicators presented above will directly influence our main indicator, especially the profit manifestation, because the companies need to maintain their capital in order to maximize their value on retail market, in Romania. (Pîrjol and Radomir, 2017). The objective of this study is to find out how the rate of commercial profitability will be influenced by all the financial indicators in retail companies in Romania. This study will focus on how financial indicators will influence the operational performance of Romanian retail companies, and how these indicators can contribute to obtain a better rate of commercial profitability in Romanian companies. This research will analyze the presented variables using the multiple linear regression model and through it will estimate the profit of every company at industry level.

\section{METHODS}

\subsection{Data selection and research methodology}

The elementary model was selected and tested by the variables that we've selected, which presents numerous companies that are existing on Romanian retail market. The data on the theoretical variables were selected from Romanian companies' reports that they send to the Romanian Finance Ministry over a period of three years, from 2015 to 2017. The selection segment was that the profit over five million EUROS and the turnover for these companies are over one billion Euros. After the applied criterion, it resulted that was selected 10 strong companies from Romanian retail market.

\subsection{Selected Variables}

In our research, the dependent variable was RCP (Rate of Commercial Profitability) because it's the strongest financial indicator with an immediate impact on selected indicators such as: turnovers, profit, total expenses, number of employees, liabilities, stocks etc. 


\subsection{Samples technique}

The study highlight the influence of some indicators selected on the evolution of the Rate of Commercial Profitability (RCP) linked with Romanian retail marketers. For this, we've studied the following financial indicators that directly influence the RCP and how these indicators will develop the RCP in Romanian retail companies.

\section{TYPE OF ANALYSES AND INTERPRETATION}

First of all, we want to present the evolution of FMCG market in Romania during last 3 years of activities, and also the importance of the performance of Romanian retail marketers and their role in our community. FMCG market was divided in different strategic groups with specific characteristics, for every section. It was identified four types of strategic groups as follows: Hypermarket Group, Cash \& Carry Group, Supermarket Group and Discounter Group. (Kahn et al., 1997)

Companies in Hypermarket Group, developed a trend that involves a large mass of consumers for which they can sell a different range of products, food and non-food goods, offering a varied and mixed range of products, in order to satisfy a huge diversity of desires. This generic group, included companies like: Kaufland, Auchan, Carrefour and also Cora, where number of employees is between 50 and 500 depending on the size and the location of the store. Companies from Cash \& Carry Strategic Group, developed a trend that involves a business to business strategy, that support local shops and other small Romanian companies, shops that have exact sectors of professional development. Likewise, this type of companies has at least a number between 70 and 120 employees, depending on the size of the store. This strategic group included just 2 companies in Romania - Metro and Selgros.

The third category of companies, are the Discounter. They developed a trend that is characterized by a system of low prices accessible to all types of consumers, in order to meet their needs. Regarding the employees number, being a small store, placed in strategic position of every city, we can find a number between 10 and 20 employees. This strategic group included 3 important companies: Profi, Lidl and Penny. The last category of companies, are the Supermarket. They developed a trend that is characterized by a combination between simplicity, profitability and quality. In last 3 years, this type of companies, are more and more common, with a successful strategic position, with a lot of benefits for the final consumer. In Romania, in this category, we just have Mega Image, which is a new business model developed over the last 4 years, in all the big cities in Romania. 
Figure $1-$ How companies evolved through last 3 years depending on market share in Romania

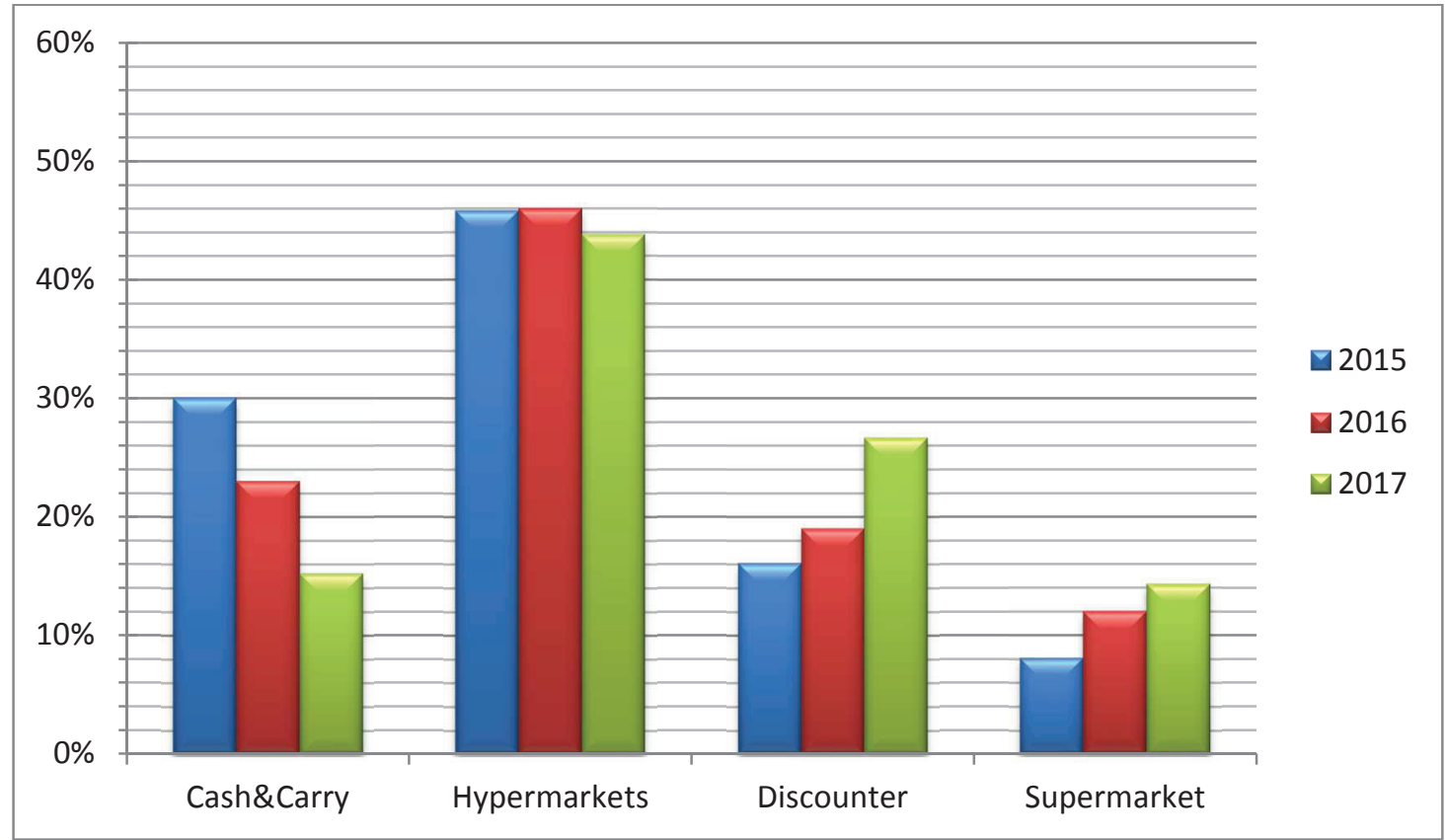

Source: based on official statements from the Ministry of Public Finances

After a short review of the above figure, the strategic group named Hypermarket is the leader of this market, with an average score below 50\% over the past three years analyzed. The Cash \& Carry strategic group has shown a decline in the last 3 years, due to a small interest of the Romanian small businesses of this concept. On the other hand, we can see a big increase of the share market for the Discounter, due to big expansions that they have on small cities from Romania. Last but not least, it's the Supermarket strategic group, with a big increase in last year due to Mega Image expansion all over the Romanian territory.

Figure 2 - Average sales from 2015 to 2017

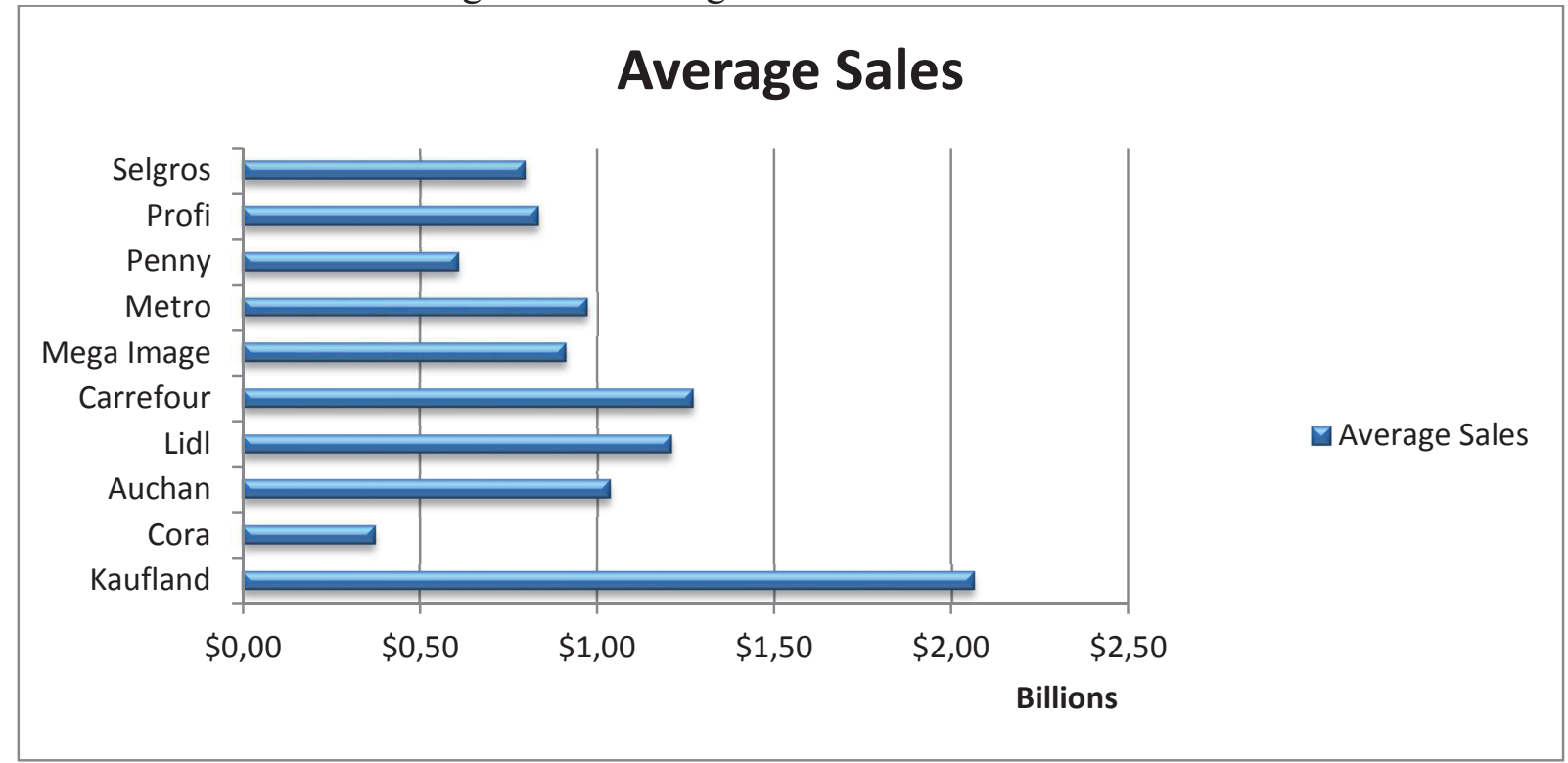

Source: based on official statements from the Ministry of Public Finances 
One of the most important and influential financial indicators is the overall performance of all the companies from Romanian retail market, through last 3 years. Figure 2 shows us, that the average sales of every company, from every strategic group. As we can see, it's a big gap between the first place, Kaufland, and the second one, Carrefour. Also, the highest level of average sales is held by Hypermarket strategic category. (Retail-FMCG.ro, 2018).

Figure 3 -Net profit from 2015 to 2017

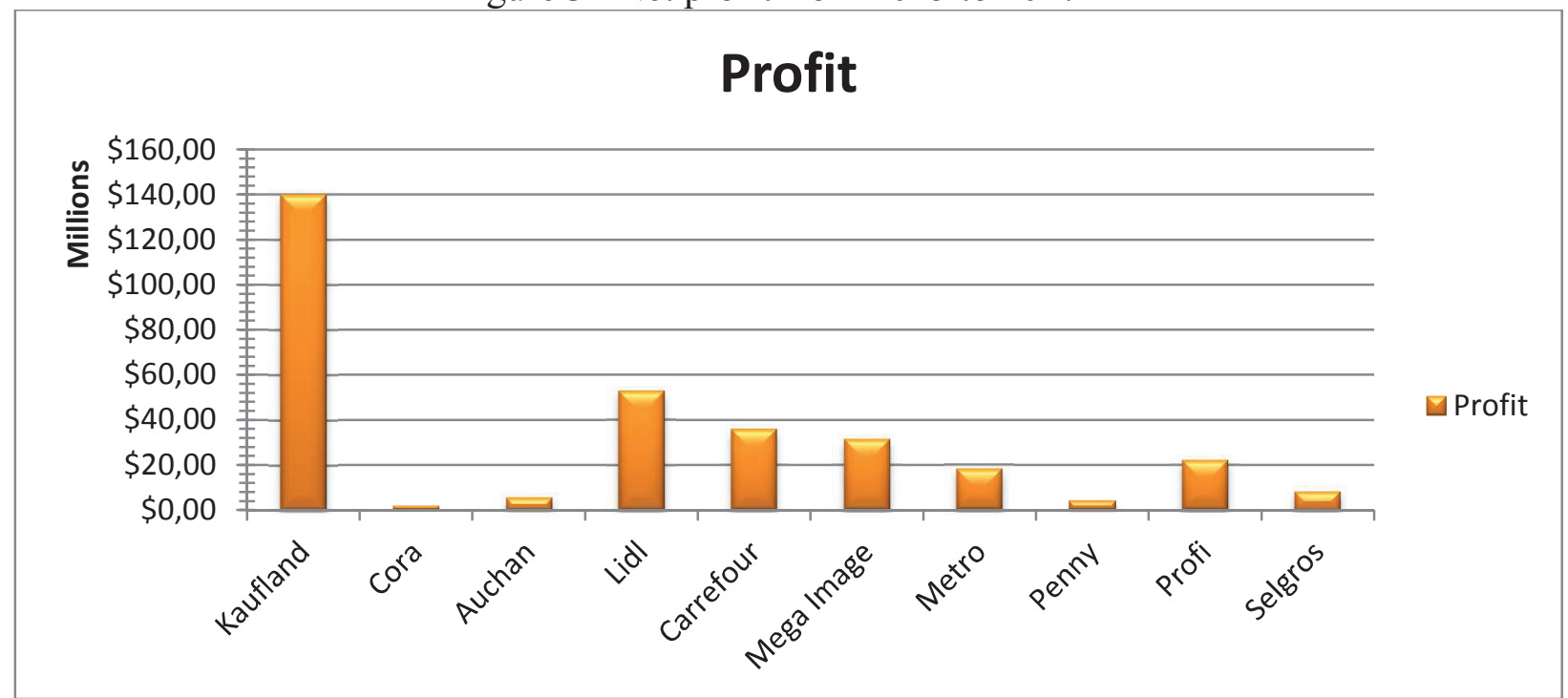

Source: based on official statements from the Ministry of Public Finances

Through the last 3 years, the market profitability was around 3,5\%. Figure 3 present that the strategic groups like Hypermarket have a profit above average and they can compete with the other strategic markets because they have the best balance between sales and profitability. On the other hand, Cash \& Carry segment recorded for the analyzed period a net profit below average, but a good one compared with the trend that is seated nowadays, when Hypermarkets and Supermarkets are in the top of the list of all the consumers.

Figure 4 - Net turnover from 2015 to 2017

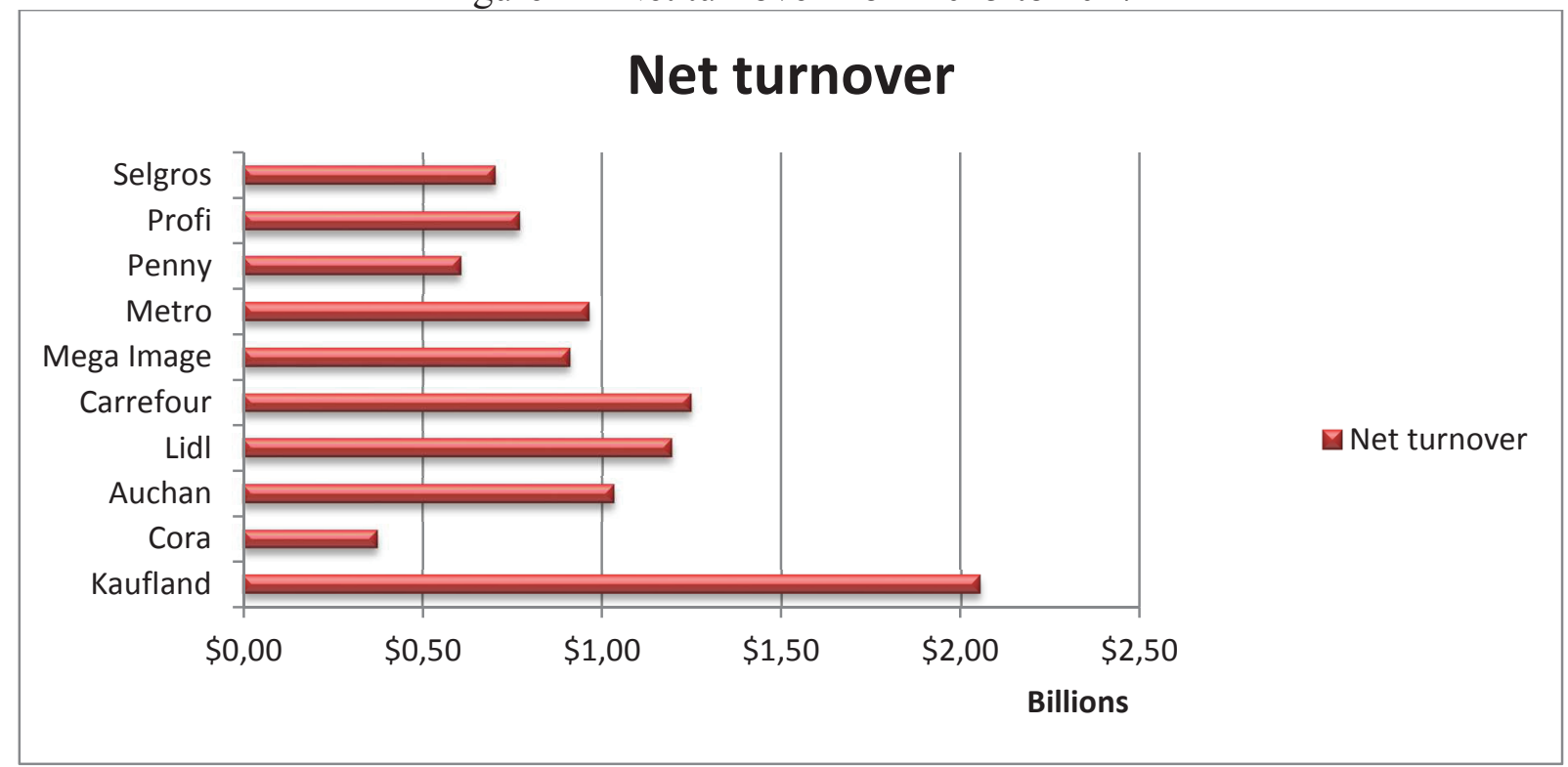

Source: based on official statements from the Ministry of Public Finances 
Figure 4 present us the net turnover from 2015 to 2017 based on official statement from the Ministry of Public Finances from Romania. As the trend was presented, we can see a gap between the Hypermarket strategic category and other categories. The net turnover has a great impact in setting the main competitor on the retail market and how the retail market will develop in the future.

Figure 5 - Average number of employees 2015 to 2017

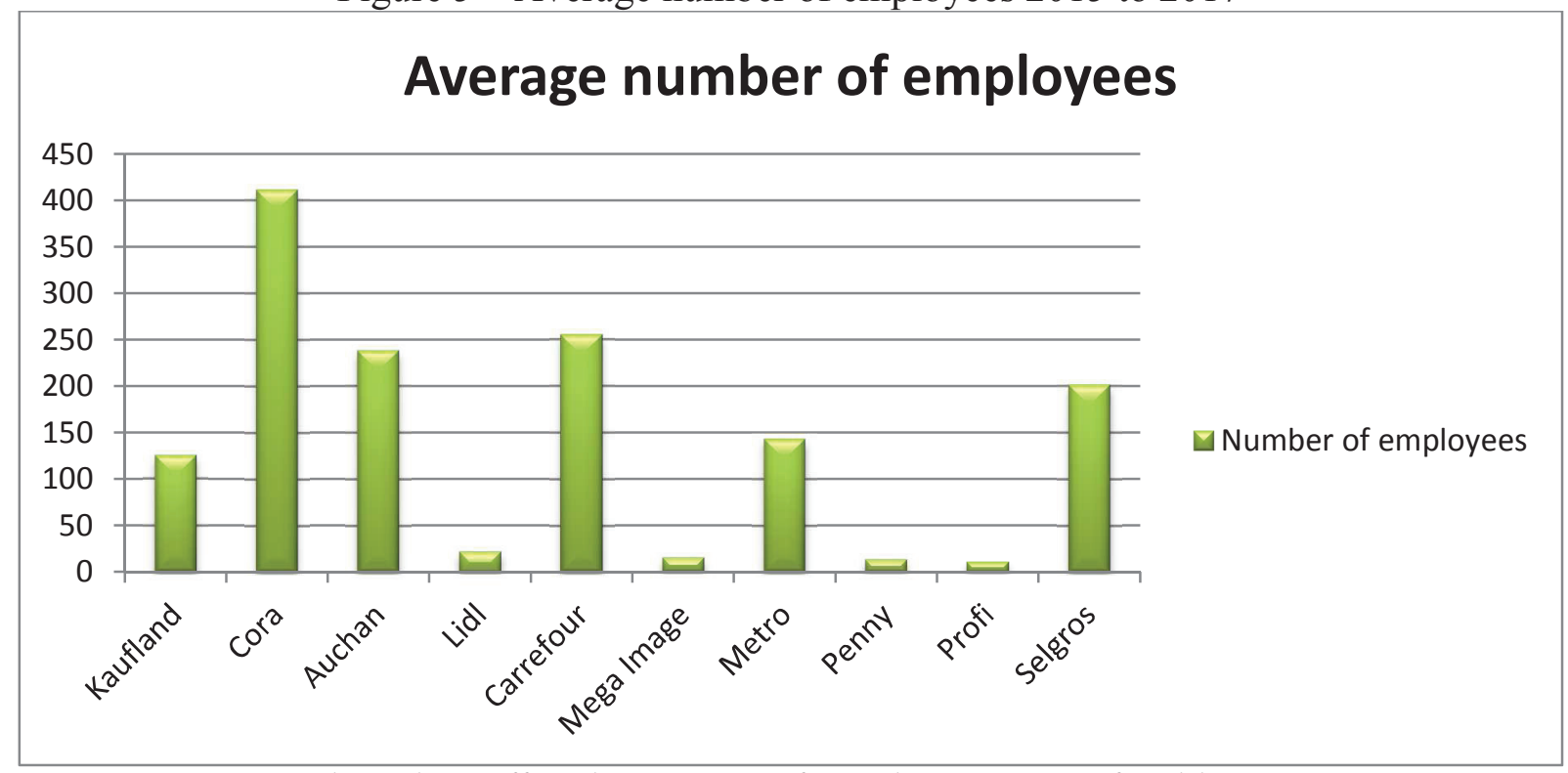

Source: based on official statements from the Ministry of Public Finances

Figure 5 presented the average number of employees from 2015 to 2017, showing that the two categories of these strategic groups, Discounters and Supermarkets have a low number of employees, depending on the location, compared with the other two strategic categories. Remarkably, after a comparison between the number of employees and the profit figures, it has been identified that Mega Image obtained the largest profit compared with other stores, with the lowest number of employees.

Furthermore, data were tested to see if they were distributed normally and if we could use this linear regression to obtain some conclusions regarding the influence of financial indicators to RCP. To find out if the tested data were normally or not, we decided to use the Shapiro-Wilk test, to discover if the data is significant (for all data to be significant, $p$ value need to be under .05). (Shapiro and Wilk, 1965; Razali and Wah, 2011)

Table 1 summarizes the result of the correlation between the financial indicators that influence our principal indicator (rate of commercial profitability - RCP). R square for our regression model has a value of .994 . This indicates that $99.4 \%$ of the rate of commercial profitability can be predicted using following eight indicators (rotation speed, loss rate, loss per employee, net profit over gross profit, net profit per employee, gross profit per employee, fixed asset rate, work productivity). Following these identified values, we acknowledged that this is a strong relationship between RCP and the other indicators.

Table 1 - Model Summary

\begin{tabular}{|c|c|c|c|c|c|}
\hline Model & $\mathrm{R}$ & R Square & Adjusted R Square & $\begin{array}{c}\text { Std. Error of the } \\
\text { Estimate }\end{array}$ & Durbin-Watson \\
\hline 1 & $.997^{\mathrm{a}}$ & .994 & .972 & .34042 & 1.534 \\
\hline
\end{tabular}


Table 2 summarize how our eight financial indicators influence the RCP and present which of them are significant and how. As can be seen in table 2, of the eight analyzed indicators, just two of them had a significant statistical influence on RCP. The regression model presents that at the level of FMCG markets in Romania, if the working productivity increase by one unit, our dependent variable, RCP, decreases with -.000004. In the same time, when the net profit per employee increase by one unit, our dependent variable increases with .000142 , with a positive relationship between them.

Table 2- Multiple linear regression results with RCP as dependent variable and financial indicators as independent variables

\begin{tabular}{|c|c|c|c|c|c|c|c|c|}
\hline \multirow{2}{*}{\multicolumn{2}{|c|}{ Model }} & \multicolumn{2}{|c|}{$\begin{array}{c}\text { Unstandardized } \\
\text { Coefficients } \\
\end{array}$} & \multirow{2}{*}{$\begin{array}{c}\text { Standardized } \\
\text { Coefficients }\end{array}$} & \multirow[t]{2}{*}{$\mathrm{t}$} & \multirow[t]{2}{*}{ Sig. } & \multicolumn{2}{|c|}{$\begin{array}{c}95.0 \% \text { Confidence Interval for } \\
\text { B }\end{array}$} \\
\hline & & B & Std. Error & & & & Lower Bound & Upper Bound \\
\hline \multirow{8}{*}{1} & (Constant) & 9.323 & 4.359 & & 2.139 & .166 & -9.433 & 28.079 \\
\hline & Fixed assets & -.007 & .015 & -.088 & -.491 & .672 & -.072 & .057 \\
\hline & Work_prod & $\begin{array}{r}-3.803 \mathrm{E}- \\
006 \\
\end{array}$ & .000 & -.555 & -4.420 & .048 & .000 & .000 \\
\hline & $\mathrm{NP} / \mathrm{BP}$ & -.069 & .047 & -.328 & -1.454 & .283 & -.272 & .135 \\
\hline & Loss per empl. & .001 & .004 & .521 & .218 & .848 & -.018 & .020 \\
\hline & Loss rate & -5.099 & 18.049 & -.687 & -.283 & .804 & -82.759 & 72.561 \\
\hline & Net profit/ empl. & .000 & .000 & 1.328 & 8.025 & .015 & .000 & .000 \\
\hline & Rotation speed & -.001 & .001 & -.432 & -1.848 & .206 & -.005 & .002 \\
\hline
\end{tabular}

Source: Authors, statistical analysis of collected data

Considering our regression model, we will assume that of the eight studied indicators, two of them have a powerful influence on RCP variable, as we shown above. Regarding ANOVA, we've identified it is statistically significant $(\mathrm{Sig}=.021)$ which means that the indicators chosen to predict the RCP have a significant influence on the dependent variable. Also, the value of Adjusted $\mathrm{R}$ is .972 , meaning that $97,2 \%$ of the dependent variable is influenced by the independent variables that we've studied and analyzed, and the P (sig) is less than 0.05 so the regression is statistically significant.

Table 3 - ANOVA

\begin{tabular}{|rl|r|r|r|r|r|}
\hline Model & & Sum of Squares & Df & Mean Square & F & Sig. \\
\hline \multirow{3}{*}{1} & Regression & 37.220 & 7 & 5.317 & 45.882 & $.021^{\mathrm{b}}$ \\
& Residual & .232 & 2 & .116 & & \\
& Total & 37.451 & 9 & & & \\
\hline
\end{tabular}

Source: Authors, statistical analysis of collected data

\section{CONCLUSION}

Our study exposed how some financial indicators could influence the rate of commercial profitability on FMCG retail companies in Romania. From the total number of indicators that we've studied, the paper showed that just two of them, net profit per employee and working productivity influence to a greater or lesser the rate of commercial profitability in this study. An important notice is that some relevant financial indicators that we've thought would influence the dependent variable, number of employees and all the fixed indicators, have no influence on the rate of commercial profitability, according to our model used above. At the beginning, we thought that more independents variables will influence the RCP variable, in order to identify how companies can increase their competitiveness and how they will try to improve their financial indicators. (Cârstea et al., 2017). Based on the research, it was identified that the Hypermarket strategic group maintain the largest of sales on Romania FMCG market, for the analyzed period. This is still happening through years, even if the Supermarket strategic 
group has encountered a colossal rise in last two years. Unfortunately, the Cash \& Carry strategic group shows a small decline through years, and that's not a good sign for their stock market.

Also, this paper is not just a small analyze of some financial indicators. It's more than that. It suggest some managerial implications that the Romanian companies should not stop over analyzing just some standard indicators to find out how they can improve their rate of commercial profitability. (Schiffman et al., 2004) As we can see, the RCP is influenced by only some independent variables, and the variables that we thought were significant, weren't. In order to formulate a strategy, FMCG companies need to focus on find how financial indicators will influence their RCP and how can keep or change some indirect variables in order to be more profitable.

\section{REFERENCES}

[1] Carstea, G., Corbos, R. A., Popescu, R. I., \& Bunea, O. I. (2017). ANALYSIS OF THE INFLUENCE OF SOME INDICATORS ON THE PROFITABILITY OF THE FMCG RETAIL MARKET IN ROMANIA. In Proceedings of the INTERNATIONAL MANAGEMENT CONFERENCE (Vol. 11, No. 1, pp. 481-492). Faculty of Management, Academy of Economic Studies, Bucharest, Romania.

[2] Ryu, J., Pistikopoulos, E.N., (2007), Multiperiod Planning of Enterprise-wide Supply Chains using an Operation Policy. Ind. Eng. Chem. Res., 46, 8058-8065

[3] Pîrjol, F., \& Radomir, L. L. (2017). The Role Of Internal Communication On The Efficiency Of The Activity In An Organization. Business Excellence and Management, 7(2), 27-45.

[4] Kahn, B.E. and McAlister, L. (1997) Grocery Revolution - The New Focus on the Consumer, New York: Addison Wesley

[5] Shapiro, S.S. \& Wilk, M.B. (1965). An Analysis of Variance Test for Normality. Biometrika, 52(3/4), 591-611.

[6] Deac, V., Dobrin, C., \& Gîrneață, A. (2016). Customer Perceived Value-An Essential Element in Sales Management. Business Excellence and Management, 6(1), 43-55.

[7] Retail-FMCG.ro. (2018). Carrefour continua sa creasca în România (+7,6\%) în al treilea trimestru din 2018. Retrieved October 18, 2018, from https://www.retailfmcg.ro/retail/carrefour-creste-in-romania.html

[8] Retail-FMCG.ro. (2017). România, cea mai mare creștere a volumului de retail dintre țările UE, în mai 2017. Retrieved July 5, 2017, from https://www.retail-fmcg.ro/analize/romaniacrestere-volum-retail-mai.html.

[9] Razali, N.M. \& Wah, Y.B. (2011). Power comparisons of Shapiro-Wilk, KolmogorovSmirnov, Lilliefors and Anderson-Darling tests, Journal of Statistical Modeling and Analytics, 2(1), 21-33.

[10] Schiffman, G. Lean, Kanuk, Leslie Lazar. (2004). Consumer Behavior. Pearson Education, Inc. 